\title{
Exploring Visitor's Socio-Demographic Characteristics and Their Satisfaction Level on Shalban Vihara and Mainamati Museum: A Cross Sectional Study
}

\author{
J.M Adeeb Salman Chowdhury* \\ Department of Statistics, Faculty of science, Comilla University, PO box -comilla-3506,Kotbari,Comilla \\ Kulsum Akter Shapna \\ Faculty of science, Comilla University
}

\begin{abstract}
Contemporary forms in tourism impose new trends conditioned by an ever-increasing number of tourists travelling in the world today. It is an undeniable fact that tourists are increasingly demanding and that it is not a simple task to satisfy all their needs and expectations. Tourist satisfaction is an important strategic weapon on which success of a tourist destination is dependent. This study was conducted to see whether travelers are satisfied with their visit to Shalban Vihara and Mainamati Museum and also to highlight factors that contribute to tourist satisfaction. The aim of this study is to offer an integrating vision of the relationship that exists between destination facilities, destination accessibility, transportation system, destination attraction, tourist satisfaction. Questionnaires were distributed to 900 visitors and tourists on Shalban Vihara and Mainamati museum, Kotbari, Comilla. Descriptive statistics, Analysis of variance and linear regression were run on the 900 useable data. The results indicate that $66 \%$ respondents were repeat visitors and 14\% were first timers. Most of the respondents are dissatisfied about destination facilities.Regression analysis revealed that destination accessibility, destination attraction, transportation system have positive result but destination facilities have negative impact on tourist satisfaction. The findings of this study $97 \%$ respondents said there is no facilities in this place and majority were dissatisfied overall satisfaction such that food facilities, rest and relaxation etc. The findings of this study could provide clear guidelines for government people, who involve in tourism sector and destination operators to develop better way to travel on Shalban Vihara and Mainamati museum.
\end{abstract}

Keywords: Tourist Satisfaction, Shalban Vihara and Mainamati museum, Facilities, Transportation system.

DOI: $10.7176 /$ JTHS/44-01

Publication date:October $31^{\text {st }} 2019$

\section{Introduction}

Tourism is a travel for recreation, religious pilgrimage, leisure, family or business purposes, usually for a limited duration. Tourism can be domestic or international. Nowadays, tourism is one of the major sources of income for many countries .Bangladesh is called the darling child of nature for her natural beauty. Rivers, coasts and beaches, archaeological sites, religious places, hills, forests, waterfalls, tea gardens abound in it. The Sundarban, Historic Mosque in city of Bagherhat, Ruins of the Buddhist Vihar at Paharpur are the three world heritage sites in Bangladesh among 1007. Bangladesh Parjatan Corporation (BPC) looks after the tourism sector in Bangladesh under the ministry of Civil Aviation and Tourism. The main responsibilities of the Ministry of Civil Aviation and Tourism include providing safe, efficient and reliable passenger and cargo transportation facilities through creating world class civil aviation infrastructure, diversification of the main tourist attractions of the country.

To observe the beauty of nature, huge amount of domestic and foreign tourists visit the country and its tourist attraction sites. In 2017, around 106000 (10 lack 6 thousand) tourists came Bangladesh to visit and enjoy its beauty. The total contribution of tourism to GDP was $4.3 \%, 3.8 \%$ to employment and $1.4 \%$ to investment in 2017 . In order to prevent the disaccords to define "Tourism", UNWTO defined it as it is indicated below: "Tourism comprises the activities of persons traveling and staying in places outside their usual environment for not more than one consecutive year for leisure, business and other purposes". Shalban Vihara is one of the famous archaeological place which is situated in Kotbari. About eight kilometers west of Comilla town, lies a range of low hills known as the Mainamati-Lalmai range which is dotted with more than 50 ancient Buddhist settlements dating from the 8 th to the 12 th centuries. Before 1200 years ago the King Bhava Deva, the fourth ruler of the Early-Deva dynasty built that place on 168 square meters of ground. It was the royal palace for the early Buddhist students. 


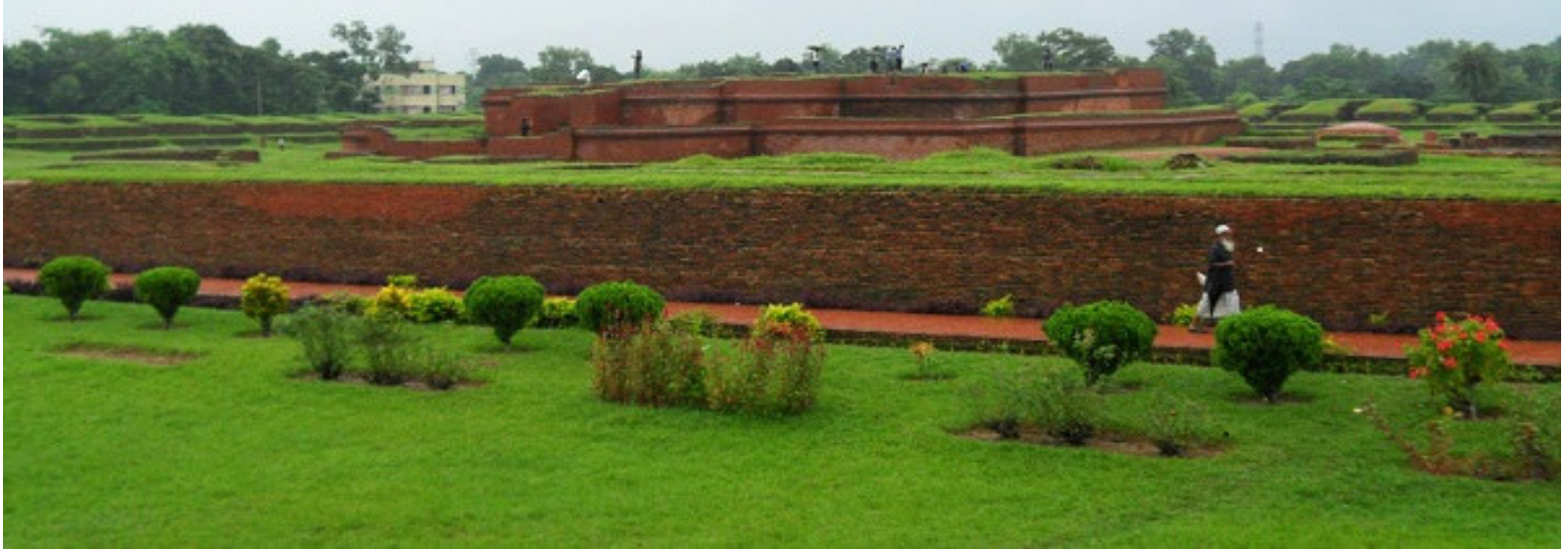

Almost at middle is the Shalban Vihara of 115 cells built around a spacious courtyard with a cruciform temple in the center. In $80^{\text {th }}$ decades many archaeological elements were found here and most of them are kept in the Mainamati Museum now. That's why many national and international visitors visit these places every day. Though it is the very renowned and historical place for tourist's attention, no research has done yet on it to know the dimensionality and improvement of the place as well as tourists satisfaction level during their visit.

\subsection{Literature Review}

Bangladesh government reformed the national tourism policy in 2010. Aims and goals of this policy is to increase employment, ensure economic development, environmental purity and sustainability (Siraj et al., 2009). Government of Bangladesh launched an act of "Protected areas of tourism and special tourism zone (Kabir et al., 2012). Bangladesh is the country in the region that has the least arrivals and revenue earned from tourism industry (Pennington and Thomsen, 2010). Tourism is one of the profitable sectors in Bangladesh (Elena et al., 2012). According to Milman and Pizam (1995) destination image consists of three main components; firstly, the product, for example, the quality of attraction; the attitude of the destination hosts and the environment; secondly the weather or climate and lastly the facilities available in the destination. Gunn (1988) states that image of a destination could be vague or clear can form in consumer mind without actual visitation. Tourism sector of Bangladesh is facing many obstacles (Arif, Islam-2011). Trust will be established when consumer will actually find the benefit they were promised prior to their visit to the destination. In many studies, Data from several secondary international sources have been used to analyze the pattern of tourism in Bangladesh. Every tourist has some expectations at the time of visiting any destination, which leads to different levels of satisfaction and dissatisfaction. The present work is conducted against this backdrop. It includes empirical study on tourist satisfaction on tourism products i.e. transports, locals, accommodation and so on. The primary purpose of this study is to know the satisfaction level of the visitors and find out the facilities expected by the visitors prepare a policy framework for improving the tourists satisfaction. Irrespective of all the challenges related to geography, climate, history, population and national economy, the country shows a number of positive development indications like increased rate of literacy rate, infrastructure and urban developments, growth of annual GDP rate etc. (The World Bank, 2010).

\subsubsection{Sources of data}

This research work is basically exploratory in nature. The aim of this research is to collect detailed information about expectations and related satisfaction of tourists visiting Shalban Vihara and Mainamati museum. It has been endeavor of the research to make an empirical study by analyzing and critically examining relevant statistical collection from primary data .The collection of primary data includes: Questionarraire; Discussion; and observations to find out tourists satisfaction level about the various tourism products like transportation, communication, safety and so on. Specific groups of samples are identified from the current group of tourists. These places are chosen because they hold the prefencial positions in terms of tourists"e arrivals in the state. Simple Random Sampling (SRS) procedure will apply to collect the required information's and further technique will follow for appropriate analysis. Study area is Shalban Vihara and Mainamati museum. It is situated in Comilla. Questionnaire has been edited in the light of the simple random sampling method. The questionnaire consists of 
15 statements, which are related to accommodation, transportation and so on. Instruments used to collect and record data for this study are open-ended interview questions and survey questionnaires. The target population of the study is those tourists who visited Shalban Vihara and Mainamati Museum during the months of November 2016 to April 2017.A random sample has been chosen from this population, with proportional grouping by sex, age, transportation etc. Data has been gathered through personal interviews carried out by professional interviews in tourist opinion survey, obtaining a total of 900 valid questionnaires.

\subsubsection{Data Analysis}

Descriptive analysis was carried out with the aims of explaining satisfaction of respondents. The statistical tests used were frequency, percentage, mean and standard deviation. Other methods including F-test and analysis of variance (one way ANOVA) were conducted in order to see a significant difference in relation to travel satisfaction based on the demographic profile of respondents. For the purpose of analyzing the collection of data, statistical techniques of mean, standard deviation, ANOVA, linear regression model has been applied.

Data related to the overall satisfaction of tourists who visit Shalban Vihara and Mainamati museum obtained from self-administered questionnaires. Descriptive analysis was utilized to determine the underlying structure of the original 11 determinants toward tourist satisfaction. Linear regression is statistical tools that enable us to determine how independent variables are related to a dependent variable. The total number of respondents is 900 . A look into demographic profile of the surveyed tourists (which includes tourists only) indicate that about $69 \%$ male and $31 \%$ female, falling in the group where as $34.8 \%$ are married and $61.9 \%$ are unmarried, $2.2 \%$ are divorced and $1.1 \%$ others (widowed). As for educational background most respondents Post-graduates $(44.33 \%)$ or had been Graduation $(35.11 \%)$, completed secondary $(9.778 \%)$ and primary school $(10.78 \%)$. It is evident that a majority of the respondents religion is Islam, than comparatively low respondent's religion are others. Tourists come in this destination for (rest and relaxation $21.3 \%$, business purpose $8.8 \%$, study tour $26.8 \%$ ) and most of them come from other purposes that are $34.5 \%$. In terms of occupation, the respondents are from various types of categories, such as Employed (21.44\%), Unemployed (8.778\%), Businessman (8.556), Students (34.33\%), others $(26.89 \%)$. It is observed that $14.44 \%$ respondent have no income, $11.67 \%$ respondent income 5000 to 10000 , 10.785 respondents income level 10000 to $20000,13.78 \%$ respondent income above 20000 and $49.33 \%$ respondent have no income.

Table 1: Travel Satisfaction Analysis:

\begin{tabular}{|c|c|c|c|}
\hline \multicolumn{2}{|c|}{ Item } & \multirow{2}{*}{$\begin{array}{c}\text { Frequency } \\
230\end{array}$} & \multirow{2}{*}{$\begin{array}{c}\text { Percentage (\%) } \\
25.6\end{array}$} \\
\hline Destination & Dhaka & & \\
\hline & Chittagong & 209 & 23.2 \\
\hline & Comilla & 277 & 30.8 \\
\hline & Rajshahi & 55 & 6.1 \\
\hline & Others & 129 & 14.3 \\
\hline \multirow[t]{3}{*}{ Tourist attraction } & Shalban Vihar & 276 & 30.7 \\
\hline & Mainamati museum & 348 & 38.7 \\
\hline & Both & 276 & 30.7 \\
\hline \multirow[t]{5}{*}{ Experience } & Strongly- agree & 594 & 66 \\
\hline & Agree & 139 & 15.4 \\
\hline & Neutral & 11 & 1.2 \\
\hline & Disagree & 30 & 3.3 \\
\hline & Strongly-disagree & 126 & 14 \\
\hline \multirow[t]{4}{*}{ Suitable months for Visit } & January-April & 603 & 67 \\
\hline & May-August & 44 & 4.9 \\
\hline & September-December & 194 & 21.6 \\
\hline & Anytime & 59 & 6.6 \\
\hline \multirow[t]{5}{*}{ Ticket price } & Strongly- agree & 504 & 56 \\
\hline & Agree & 208 & 23.1 \\
\hline & Neutral & 32 & 3.6 \\
\hline & Disagree & 24 & 2.7 \\
\hline & Strongly- disagree & 132 & 14.7 \\
\hline \multirow[t]{5}{*}{ Transportation system } & Strongly- agree & 385 & 42.8 \\
\hline & Agree & 198 & 22.0 \\
\hline & Neutral & 45 & 5.0 \\
\hline & Disagree & 48 & 5.3 \\
\hline & Strongly- disagree & 224 & 24.9 \\
\hline
\end{tabular}




\begin{tabular}{|l|l|c|c|}
\hline \multicolumn{2}{|c|}{ Item } & Frequency & Percentage (\%) \\
\hline \multirow{5}{*}{ Safety and Security } & Strongly- agree & 392 & 43.6 \\
\cline { 2 - 4 } & Agree & 147 & 16.3 \\
\cline { 2 - 3 } & Neutral & 69 & 7.7 \\
\cline { 2 - 3 } & Disagree & 108 & 12.0 \\
\cline { 2 - 3 } & Strongly- disagree & 184 & 20.4 \\
\hline Main reason for Visiting & Rest and relaxation & 193 & 21.4 \\
\cline { 2 - 4 } & Business purpose & 79 & 8.8 \\
\cline { 2 - 4 } & Visiting to meet with friends or relatives & 77 & 8.6 \\
\cline { 2 - 4 } & Study tour & 242 & 26.9 \\
\cline { 2 - 4 } & Others & 309 & 34.3 \\
\hline Facilities & Restaurant & 6 & .7 \\
\cline { 2 - 4 } & Shopping & 18 & 2.0 \\
\cline { 2 - 4 } & None & 876 & 97.3 \\
\hline
\end{tabular}

Table 1 describes the respondent's views on travel satisfaction. The findings showed that most respondents were satisfied with the tourist attraction for their district from destination (Dhaka 25.6\%,Chittagong $23.2 \%$,Comilla $30.8 \%$,Rajshahi $6.1 \%$,Others $14.3 \%$ ).In addition, the study also showed that respondents have experience with (Strongly Agree $66 \%$, Agree $15.4 \%$, Neutral 1.2, Disagree 3.3\%,Strongly disagree $14 \%$ ).It is evident that respondents thought suitable months for visiting this place where January-April $67 \%$, May-August $4.9 \%$, September-December $21.6 \%$, Anytime $6.6 \%$. Respondents were satisfied this reason they were come more times in this place. Most of the respondents were satisfied about ticket price than others things. The findings related to transportation system that they were generally satisfied with the transport factors in this place strongly agree $42.8 \%$ tourist. Analysis also showed most of the tourist comes for study tour and rest, relaxation than other purposes. In fact of tourist facilities mainly for food system is not good, also shopping facilities is not here and also others. But in the other hand respondents were also satisfied about safety and security.

Table 2: Perception of Overall Satisfaction

\begin{tabular}{|l|l|l|l|}
\hline Item & Frequency & Percentage (\%) \\
\hline $\begin{array}{l}\text { Overall, how } \\
\text { satisfied are }\end{array}$ you with your & Strongly- agree & 271 & 30.1 \\
\cline { 2 - 4 } \begin{tabular}{l} 
Safety? \\
\cline { 2 - 4 }
\end{tabular} & Neutral & 238 & 26.4 \\
\cline { 2 - 4 } & Disagree & 41 & 4.6 \\
\cline { 2 - 4 } & Strongly- disagree & 70 & 7.8 \\
\hline
\end{tabular}

\subsubsection{Methodology}

Table 3 below describes the findings of analysis of variance (ANOVA one way) on travel satisfaction variables according to the demographic profile of respondents. As shown in the table, the data showed significant difference in gender but no difference marital status and education level of travel satisfaction ( $p>0.05)$.

The studies the designed hypotheses are as follows:

$\boldsymbol{H}_{\mathbf{0 1}}$ : There is a positive relationship between the destination facilities and tourist satisfaction.

$\boldsymbol{H}_{\mathbf{0 2}}$ : There is a positive relationship between the destination accessibility and tourist satisfaction

$\boldsymbol{H}_{\mathbf{0 3}}$ : There is a positive relationship between the transportation system and tourist satisfaction.

$\boldsymbol{H}_{\mathbf{0 4}}$ : There is a positive relationship between the destination attraction and tourist satisfaction.

Table 3: Analysis of Variance (ANOVA) on Travel Satisfaction

\begin{tabular}{|l|l|l|}
\hline Variables & ANOVA & Results \\
\hline Gender & $\mathrm{F}=10.739, \mathrm{p}=.001$ & Significant \\
\hline Marriage status & $\mathrm{F}=1.812, \mathrm{p}=.143$ & Not Significant \\
\hline Educational level & $\mathrm{F}=2.064, \mathrm{P}=.103$ & Not Significant \\
\hline Occupation & $\mathrm{F}=6.266, \mathrm{p}=.000$ & Significant \\
\hline Home destination & $\mathrm{F}=2.506, \mathrm{p}=.041$ & Significant \\
\hline Religion & $\mathrm{F}=4.322, \mathrm{p}=.002$ & Significant \\
\hline
\end{tabular}

The result showed in Table 3 indicated there was a significant difference between Occupation, with travel satisfaction $(\mathrm{p}<0.01)$. Most of respondents were students and there was no income in this reason they were most satisfied.

The study also found that there was a significant difference between the home district with traveler satisfaction $(\mathrm{p}<.005)$. Data showed that respondents from a higher travelling satisfaction than respondents from Comilla (49.56\%), Chittagong (16.89\%), Rajshahi (13.78\%), Dhaka (17.78\%) and others $2 \%$.In addition to 
Religion were also found significant difference in travelling satisfaction $(\mathrm{p}<.005)$. As for shows that higher travelling satisfaction are Muslims $(87 \%)$ than others.Destination facilities were proposed to have positive relationship with tourist satisfaction in this study. This sub-hypothesis was tested by using a linear regression analysis as shown in Table 4.

Table 4: Linear Regression for Impact of Destination Facilities, Destination accessibility, Transportation system, Destination attraction on Tourist Satisfaction

\begin{tabular}{|l|l|l|l|l|l|}
\hline Independent Variable & \multicolumn{4}{l|}{ Dependent Variable: Tourist Satisfaction } & \\
\hline & $\mathrm{r}$ & $\mathrm{R}^{2}$ & $\beta$ & $\mathrm{t}$ & Sig. \\
\hline Destination Facilities & .074 & .006 & -.074 & 7.000 & .000 \\
\hline Destination Accessibility & .102 & .010 & .120 & 32.558 & .000 \\
\hline Transportation system & .012 & .000 & .012 & 27.959 & .000 \\
\hline Destination Attraction & .038 & .001 & .038 & 19.685 & .000 \\
\hline
\end{tabular}

Table 4 shows that destination facilities are a significant predictor of tourist satisfaction. The regression results indicated that destination facilities had a negative relationship with tourist satisfaction $(\beta=-.074$, $\mathrm{P}=.000$ ). More specially, destination facilities explain $\left(\mathrm{R}^{2}\right) 0.06 \%$ of the variance in tourist satisfaction. Consequently, the overall statistical results confirmed that relationship and therefore hypothesis $\mathrm{H}_{01}$ is rejected. In this study, Destination accessibility was proposed to have a positive relationship with tourist satisfaction. A linear regression analysis was conducted to test this sub-hypothesis, and the results are presented in Table 4. The regression results showed that destination accessibility (ticket price) is a good significant predictor of tourist satisfaction as shown in Table 4, destination accessibility is positively related to tourist satisfaction $(\beta=.120, \mathrm{P}=.000)$. More specially, destination explains $\left(\mathrm{R}^{2}\right) .01 \%$ of the variance in tourist satisfaction. However, the overall statistical results indicated that destination accessibility positively influenced tourist satisfaction. Accordingly, hypothesis $\mathrm{H}_{02}$ is accepted. Consequently, hypothesizes was proposed to be some rejected and some accepted in this study. Regression results showed that service quality (destination facilities, destination accessibility, destination attraction) is a good significant predicator of tourist satisfaction as shown in Table 4 , Transportation system is positively related to tourist satisfaction $(\beta=.012, \mathrm{P}=.000)$. More specifically, however, the overall statistical results indicated that transportation system positively influenced tourist satisfaction. As a result, hypothesis (study hypothesis) is accepted which confirmed the positive relationship between transportation system and tourist satisfaction.

As table 4 shows, destination attractions (museum) are moderately related to tourist satisfaction $(\beta=.038$, $\mathrm{P}=.000$ ). The regression results showed that destination attractions is a significant predicator of tourist satisfaction, more specifically, destination attractions explain $\left(\mathrm{R}^{2}\right) .01 \%$ of the variance in tourist satisfaction. The overall statistical results indicated that destination attractions positively impacted tourist satisfaction. Thus, hypothesis $\mathrm{H}_{04}$ is accepted. The study findings concluded that destination accessibility, destination attractions, transportation system has great effect on overall tourist satisfaction but destination facilities were not satisfied for tourist. Such that rest house, food facilities, toilet etc. There are many things are not here. This study confirmed that has a positive relationship with tourist satisfaction. These results suggest that tourist satisfaction can be enhanced by raising the level of transportation system throughout destination accessibility and destination attractions. It was also found that tourists in Shalban Vihara and Mainamati Museum are moderately satisfied with the level of tourism place. Some facilities are good but which plays vital role for tourist attraction such that food, rest house etc are not here. In this reason most of tourist from far place doesn't want to come here anymore time.

\subsubsection{Conclusion}

The study's results are considered to be valuable to destination in Shalban Vihara and Mainamati museum in evaluating the level of their satisfaction. Therefore, this study suggests that this destination has a negative impact on the level of tourist satisfaction about destination facilitates. The study provided as well as the experience felt by tourists have been found to achieve and fulfill the tourist needs while visiting this place. It is very important that tourist who are strongly dissatisfied with their visit and why? Also share lacking's or reasons of this places with others. For country, tourism capable of having significant influences on economic development. Bangladesh has an enormous potential to develop tourism because of its attractive natural beauty, which can be experienced all throughout the land. Bangladesh that have received but no attention, places which are still unknown and waiting to be launched for the global community. I $n$ this case Bangladesh government should take necessary steps to enrich tourism sector like that Shalban Vihara and Mainamati museum. Because its play a vital role to enrich tourism sector to earn more money. If Bangladesh govt. take some necessary steps it will be good for tourist. After many years our next generation will know about archeological site such as Shalban Vihara and Mainamati museum and also will know which our nation's culture was so many years ago, which things they were used, which things they were ware etc. 


\section{Reference}

Enrique Martin Armario, “Tourist satisfaction: An analysis of its antecedents”, 382pp.

Ghazal Masarrat (2012), “Tourists Satisfaction towards Tourism Products and Market: A Case Study of Uttaranchal", Research Associate, Indian Institute of Management, Lucknow, 25pp.

Munir Salleh Khatijah Omar Azizul Yadi Yaakop(2013), “Tourist Satisfaction in Malaysia”, Faculty of Business and Economics Universiti Malaysia Terengganu Malaysia,226pp.

Elena, M., Lee, M. H., Suhartono, H., Hossein, I., Rahman, N. H. A., \& Bazilah, N. A. (2012). Fuzzy Time Series and Sarima Model for Forecasting Tourist Arrivals to Bali. Jurnal Teknologi, 57(1).

Mukhles Al-Ababneh,(2013), "Service Quality and its Impact on Tourist Satisfaction” Petra College for Tourism and Archaeology Al-Hussein Bin Talal University Ma'an, Jordan,177pp.

Gursoy, D., McCleary, K. W. and Lepsito, L. R. (2007). Propensity to complain: effects of personality and behavioral factors. " Journal of Hospitality \& Tourism Research", 31 (3), 358-386.

Milošević, S. (2012), "Importance of Satisfaction and Guests Experience in Hotel business Organizations",Tims. Acta 6 (1), pp. 1-9.

Kabir, M. A., Kawsar Jahan, M., Adnan, N., \& Khan, N. (2012). Business Model of E-Tourism for Developing Countries. International Journal of Computer and Information Technology, 3(1), 30-34.

Ferrario, F.F. (1970). Evaluation of Tourist Resources-An applied Methodology. Journal of Transport Research, $17(3): 18-22$.

Micheal, Lowenstein. (2001). "Customer Satisfaction mindset and metrics", The Wise Marketer,www.thewisemarketer.com.

Siraj, S.B., Alam, G. M., Hoque, K. E., Khalifa, M. T. B., \& Ghani, M. F. B. A. (2009). The role of agriculture education and training on agriculture economics and national development of Bangladesh. Afr. J. Agric. Res, 4(12), 1334-1350.

V. Middleton, A. Fyall, M. Morgan, A. Ranchhod Marketing in Travel and Tourism, Butterworth Heinemann, Routledge; 4th edition (2009)

Del Bosque I.R., San Martín, H. (2008), “Tourist Satisfaction: A Cognitive-Affective Model”, Annals of Tourism Research, 35 (2), pp. 551-573.

Pennington, J. W., \& Thomsen, R. C. (2010). A semiotic model of destination representations applied to cultural and heritage tourism marketing. Scandinavian Journal of Hospitality and Tourism, 10(1), 33-53.

Arif and Islam (2011): Opportunities of tourism in Bangladesh: International journal of research in commerce, IT and management Volume No.1, Issue No.6. 